\title{
PENGARUH BIAYA KUALITAS TERHADAP PRODUK RUSAK DITINJAU DARI PERSEPSI KARYAWAN PADA PT FANINDA JAYA MEUBEL KABUPATEN GORONTALO
}

\author{
Hasanuddin $^{1 *}$, Dewi Sartika ${ }^{2}$, Muhammad Anas ${ }^{3}$ Hariatih $^{4}$ \\ Universitas Gorontalo ${ }^{1}$, Universitas Ichsan Gorontalo ${ }^{2,3}$, Institut Tehnologi dan Bisnis Nobel Indonesia ${ }^{4}$ \\ Email :achankbagu.bone@gmail.com ${ }^{1}$, dewisartika@gmail.com², Muhammadanas@gmail.com³ \\ hariatih@gmail.com ${ }^{4}$
}

\begin{abstract}
Abstrak
Metode analisis yang digunakan dalam penelitian ini adalah analisis linier berganda dengan variabel independen: biaya pencegahan (X1), biaya penilaian (X2), biaya kegagalan internal (X3), biaya kegagalan eksternal (X4) dan variabel dependen adalah produk rusak (Y). Tujuan penelitian ini adalah mengetahui tingkat persentase pengaruh biaya pencegahan, biaya penilaian, biaya kegagalan internal, biaya kegagalan eksternal terhadap produk rusak baik pengaruh secara simultan maupun pengaruh secara parsial dengan menggunakan kuesioner untuk mengetahui persepsi karyawan terhadap variabel penelitian. Dengan menggunakan sampel sebanyak 81 responden karyawan. Hasil penelitian ini menunjukkan bahwa biaya kualitas secara parsial yang terdiri dari variabel biaya pencegahan (X1) memiliki pengaruh positif dan signifikan terhadap produk rusak sebesar 44,3\% variabel biaya penilaian (X2) memiliki pengaruh positif dan signifikan terhadap produk rusak sebesar $24,4 \%$ variabel biaya kegagalan internal (X3) memiliki pengaruh positif dan signifikan sebesar $22,1 \%$ dan variabel biaya kegagalan eksternal memiliki pengaruh positif dan signifikan terhadap produk rusak sebesar $31,3 \%$ dan pengaruh secara simultan meliputi biaya pencegahan (X1), biaya penilaian (X2), biaya kegagalan internal (X3) dan biaya kegagalan eksternal (X4) secara positif dan signifikan terhadap produk rusak pada PT. Faninda Jaya Meubel sebesar 54,7\% sedangkan sebesar 45,3\% dipengaruhi oleh variabel lain yang tidak diteliti yaitu pengalaman tenaga kerja dan biaya listrik.

Kata kunci: Biaya Kualitas, Produk Rusak
\end{abstract}

\begin{abstract}
The analytical method used in this study is multiple linear regression analysis with independent variables: prevention costs (X1), appraisal costs (X2), internal failure costs (X3), external failure costs (X4) and the dependent variable is defective products (Y). The purpose of this study was to determine the percentage level of the effect of prevention costs, appraisal costs, internal failure costs, external failure costs to damaged products, both simultaneous and partial effects by using a questionnaire to determine employee perceptions of research variables. By using a sample of 81 employee respondents. The results of this study indicate that the cost of quality partially consisting of the variable cost of prevention (X1) has a positive and significant effect on damaged products by $44.3 \%$, the variable cost of assessment (X2) has a positive and significant effect on damaged products by $24.4 \%$. The internal failure cost variable (X3) has a positive and significant effect of $22.1 \%$ and the external failure cost variable has a positive and significant effect on damaged products by $31.3 \%$ and the simultaneous influence includes prevention costs (X1), appraisal costs (X2), internal failure costs (X3) and external failure costs (X4) positively and significantly on damaged products at PT. Faninda Jaya Furniture is $54.7 \%$ while $45.3 \%$ is influenced by other variables not examined, namely labor experience and electricity costs Keywords: Quality Cost, Damaged Product.
\end{abstract}




\section{PENDAHULUAN}

Tingginya kualitas produk akan mendapatkan harga yang lebih bersaing dan akan selalu menjadi bagian dari yang diinginkan oleh pelanggan. Perusahaan yang memiliki produk yang baik pasti akan mudah mendapatkan keuntungan yang diharapkan, karena produk yang ditawarkan akan laku terjual. Seiring dengan tingginya kualitas produk suatu perusahaan atau organisasi akan menjadi incaran di pasar yang berskala besar baik nasional maupun pasar internasional.

Kerusakan pada sebuah produk dalam perusahaan harus dihindari, karena jika dibiarkan maka akan berakibat terhadap proses kenaikan harga pokok produksi dala sebuah perusahaan. Oleh karena itu perusahaan sedapat mungkin akan melakukan penyiapan anggaran dalam rangka mengganti biaya produksi rusak yang diakibatkan kekurang hati-hatian. Sehingganya perusahaan bisa menghindari kerugian. Jika terdapat produk rusak dapat mengakibatkan berkurangnya produk jadi. Untuk mengatasi biaya produksi terkait produk rusak dan untuk membuat perusahaan terhindar dari kerugian, maka biaya yang dipergunakan dalam membuat produk yang dimaksud dibebankan pada hasil produk yang tidak terjadi kerusakan, yang mengakibatkan pada tingginya harga pokok produksi.

Menurut Firdaus dalam Munawarah (2018) biaya (cost) adalah pengeluaranpengeluaran atau nilai pengorbanan untuk memperoleh barang atau jasa yang berguna untuk masa yang akan datang, atau mempunyai manfaat melebihi satu periode akuntansi. Biaya pencegahan adalah biaya yang terjadi untuk mencegah terjadinya kegagalan produk. Biaya penilaian adalah biaya yang terjadi untuk mendeteksi kegagalan produk. Biaya kegagalan adalah biaya yang terjadi ketika suatu produk gagal. Kegagalan tersebut dapat terjadi secara internal maupun eksternal. Biaya kegagalan internal adalah biaya yang terjadi selama proses produksi. Biaya kegagalan eksternal adalah biaya yang terjadi setelah produk dijual. System biaya kualitas memungkinkan perusahaan untuk mengukur tingkat keberhasilan pada perbaikan mekanisme meningkatkan kualitas. Ini sesuai dengan kebutuhan perusahaan yang selalu melakukan upaya perbaikan dari setiap mekanisme peningkatan kualitas. Sehingga perusahaan akan melakukan proses identifikasi biayabiaya yang akan dikeluarkan pada tiap-tipa identifikasi biaya dalam rangka pengendalian terhadap kualitas produk yang ingin dicapai.

Ada dua hal yang menyebabkan terjadinya produk rusak yaitu: pertama, produk rusak yang diakibatkan kegiatan normal perusahaan atau produk rusak normal dan produk rusak karena kekeliruan atau produk rusak abnormal (Mulyadi, 2012). Bila terjadi produk rusak dalam perusahaan, maka akan dilakukan perhitungan sebagai produk rusak dan dapat menyerap biaya produksi. Perlakuan akuntansi terhadap produk rusak harus berdasarkan pada sifat kerusakanny, yaitu bersifat normal atau tidak normal dalam perlakuan terhadap produk tersebut juga akan didasarkan pada laku tidaknya produk itu untuk dijual.

Pada sebuah perusahaan tentu memiliki kebijakan standar terkait kualitas suatu produk, maka perusahaan sedapat mungkin melalukan peningkatan terhadap kualitas produk yang dihasilkan dengan berbagai perlakuan terhadap harga yang memungkinakan tidak didapatnya produk rusak dimasa yang akan datang. Maka kemudian pelanggan atau konsumen diharapkan untuk tetap memilih produk yang telah dihasilkan sehingga tidak beralih ke produk yang lain. Dalam menghasilkan produk yang berkualitas, maka selayaknya perusahaan akan melakukan pendeteksian yang ketat sehingga dapat meningkatkan kualitas produk yang dihasilkan. Harapannya adalah akan memperoleh 
hasil yang maksimal. Ketika dilakukan peningkatan kualtias maka produk rusak dapat teratasi, sehingga dapat meningkatkan keutungan bagi perusahaan, dengan peningkatan kualitas yang dihasilkan maka akan dapat menekan biaya-biaya dan menaikkan tingkat pangsa pasar.

Terkait masalah produk rusak, perusahaan melakukan penyesuaian terhadap pengendalian kualitas yang berbarengan dengan pengeluaran atas biaya yang ditimbulkan dalam rangka meningkatan kualitas yang arahnya adalah meminimalkan kerusakan produk. Ketika didapatkan beberapa produk rusak yang tidak sesuai kualifikasi standar, maka akan besar juga biaya yang dikeluarkan oleh perusahaan. Masalah ini dapat meningkatkan kerugian terhadap perusahaan, karena akan mengeluarkan biaya kualitas yang tinggi. Oleh karena itu maka biaya kualitas menjadi hal yang sangat penting untuk dipenuhi perusahaan dalam melakukan pencegahan terhadap produk yang rusak.

PT. Faninda Jaya Meubel melakukan upaya peningkatan kualitas dengan mengeluarkan beberapa biaya untuk digunakan dalam mengatasi masalah produk rusak, meskipun memang masih ditemukan produk yang masih rendah kualitasnya. Jenis produk bisa dikategorikan rusak berdasarkan pada kualitas produk itu sendiri, misalnya kursi yang diproduksi masih sering terjadi kerusakan pada bagian kaki kursi saat pemindahan barang dari gudang ke show room yang menyebabkan kaki kursi goyang atau terlepas. Hal ini terjadi karena kekurang hati-hatian dan ditemukannya beberapa produk yang rusak. Terkait data tentang produk yang telah dihasilkan, terjadi produk rusak dan presentase produk rusak PT. Faninda Jaya Meubel untuk setiap bulannya pada tahun 2014-2015 dapat dilihat pada table dibawah ini:

Tabel 1. Data produk, produk rusak, dan persentase produk rusak PT. Faninda Jaya

\begin{tabular}{|c|c|c|c|c|c|c|}
\hline \multirow{3}{*}{ Bulan } & \multicolumn{7}{|c|}{2014} & \multicolumn{3}{c|}{$\mathbf{2 0 1 5}$} \\
\cline { 2 - 7 } & $\begin{array}{c}\text { Jumlah } \\
\text { Produk }\end{array}$ & $\begin{array}{c}\text { Jumlah } \\
\text { Produk } \\
\text { Rusak }\end{array}$ & $\%$ & $\begin{array}{c}\text { Jumlah } \\
\text { Produk }\end{array}$ & $\begin{array}{c}\text { Jumlah } \\
\text { Produk } \\
\text { Rusak }\end{array}$ & $\%$ \\
\hline Jan & 412 & 33 & $8.0 \%$ & 498 & 33 & $6.6 \%$ \\
\hline Feb & 408 & 25 & $6.1 \%$ & 535 & 40 & $7.5 \%$ \\
\hline Maret & 419 & 32 & $7.6 \%$ & 539 & 37 & $6.9 \%$ \\
\hline April & 401 & 29 & $7.2 \%$ & 540 & 39 & $7.2 \%$ \\
\hline Mei & 399 & 26 & $6.5 \%$ & 582 & 45 & $7.7 \%$ \\
\hline Juni & 417 & 35 & $8.4 \%$ & 601 & 42 & $7.0 \%$ \\
\hline Juli & 422 & 32 & $7.6 \%$ & 577 & 32 & $5.5 \%$ \\
\hline Agst & 503 & 40 & $8.0 \%$ & 464 & 43 & $9.3 \%$ \\
\hline Sept & 414 & 25 & $6.0 \%$ & 534 & 37 & $6.9 \%$ \\
\hline Okt & 404 & 30 & $7.4 \%$ & 497 & 35 & $7.0 \%$ \\
\hline Nov & 421 & 34 & $8.1 \%$ & 548 & 40 & $7.3 \%$ \\
\hline Des & 432 & 27 & $6.3 \%$ & 553 & 45 & $8.1 \%$ \\
\hline Jumlah & 5052 & 368 & $7.3 \%$ & 6468 & 468 & $7.2 \%$ \\
\hline
\end{tabular}

Sumber : PT. Fanida Jaya Meubel

Biaya kualitas yang dikeluarkan oleh perusahaan tidak berbanding lurus dengan hasil dari produk yang dihasilkan karena masih ditemukan beberapa produk rusak hingga 
mencapai 7-8\% dari produksi yang dihasilkan, meskipun perusahaan sudah menetapkan nilai standar produk yang rusak sebesar 5\%. Penetapan standar rusak 5\% terhadap produk rusak di PT. Faninda Jaya Meubel, dikarenakan pihak perusahaan bisa memperbaiki kerusakan sebesar 5\% sebelum adanya pengiriman produk berikutnya. Tujuan penelitian ini adalah mengetahui tingkat persentase pengaruh biaya pencegahan, biaya penilaian, biaya kegagalan internal, biaya kegagalan eksternal terhadap produk rusak baik pengaruh secara simultan maupun pengaruh secara parsial dengan menggunakan kuesioner untuk mengetahui persepsi karyawan terhadap 270ariable penelitian.

\section{METODE PENELITIAN}

\section{Jenis Penelitian}

Penelitian ini merupakan penelitian dengan pendekatan deskriftif kuantitatif. Sumber data adalah data primer. Dengan menggunakan 270ariab pengumpulan data dengan penyebaran kuesioner.

\section{Prosedur}

Penelitian ini diawali dengan adanya fenomena tentang jumlah produk, produk rusak dan persentase produk rusak. Dari fenomena ini kemudian dirumuskan masalah penelitian terkait dengan persepsi karyawan mengenai biaya kualitas dan produk rusak. Selanjutnya dilakukan kajian data primer yang telah didapatkan melalui penyebaran kuesioner terhadap 81 orang responden pada PT. Faninda Jaya Meubel. Selanjutnya dilakukan pengumpulan data, pengujian data dan analisis data untuk menguji hipotesis yang mempunyai variasi tertentu yang ditetapkan oleh peneliti untuk dipelajari dan kemudian ditarik kesimpulannya (Sugyono, 2012).

\section{Instrumen dan Operasional Variabel}

Instrumen penelitian ini berupa kuesioner yang disusun berdasarkan indicator variable penelitian yaitu sebagai berikut:

Tabel 2. Instrumen operasional Variabel

\begin{tabular}{|c|c|c|c|}
\hline Variabel & Sub variabel & Indikator-indikator & Skala \\
\hline \multirow[t]{3}{*}{$\begin{array}{l}\text { Biaya } \\
\text { kualitas } \\
(\mathrm{X})\end{array}$} & $\begin{array}{l}\text { Biaya } \\
\text { pencegahaan } \\
(\mathrm{X} 1)\end{array}$ & $\begin{array}{l}\text { a. Teknik perencanaan kualitas } \\
\text { b. Tinjauan produk baru } \\
\text { c. Rancangan proses atau produk } \\
\text { d. Pengendalian proses } \\
\text { e. Pelatihan } \\
\text { f. Audit kualitas }\end{array}$ & Ordinal \\
\hline & $\begin{array}{l}\text { Biaya } \\
\text { penilaian }(X 2)\end{array}$ & $\begin{array}{l}\text { a. Pemeriksaan pengujian bahan baku yang } \\
\text { dibeli } \\
\text { b. Pemeriksaan pengujian produk } \\
\text { c. Pemeriksaan kualitas produk } \\
\text { d. Evaluasi persediaan }\end{array}$ & Ordinal \\
\hline & $\begin{array}{l}\text { Biaya } \\
\text { kegagalan } \\
\text { internal (X3) }\end{array}$ & $\begin{array}{l}\text { a. Sisa bahan (scrap) } \\
\text { b. Pengerjaan ulang } \\
\text { c. Biaya untuk memperoleh material (bahan } \\
\text { baku) } \\
\text { d. Factory contact engineering }\end{array}$ & Ordinal \\
\hline
\end{tabular}




\begin{tabular}{|l|l|l|c|}
\hline Variabel & Sub variabel & \multicolumn{1}{|c|}{ Indikator-indikator } & Skala \\
\hline & $\begin{array}{l}\text { Biaya } \\
\text { kegagalan } \\
\text { eksternal (X4) }\end{array}$ & $\begin{array}{l}\text { a. Biaya penanganan keluhan selama masa } \\
\text { garansi }\end{array}$ & Ordinal \\
& & $\begin{array}{l}\text { b. Baya penanganan keluhan di luar masa } \\
\text { garansi }\end{array}$ & \\
& & $\begin{array}{l}\text { c. Prayanan (service) produk } \\
\text { e. Biaya penarikan kembali produk }\end{array}$ & \\
\hline $\begin{array}{l}\text { Produk } \\
\text { rusak (Y) }\end{array}$ & & $\begin{array}{l}\text { a. Sifat penyebab kerusakan } \\
\text { b. Masalah akuntansi } \\
\text { c. Menyerap biaya-biaya }\end{array}$ & Ordinal \\
& & $\begin{array}{l}\text { d. Perbaikan } \\
\text { e. Proses produksi }\end{array}$ & \\
\hline
\end{tabular}

Sumber variabel $X$ : Fandi dan Anastasia (2003 : 36-39)

Sumber variabel $Y$ : Mulyadi $(2015: 302)$

\section{Metode Analisis}

Metode analisis digunakan untuk memastikan variabel independen berpengaruh terhadap variabel dependen, serta adanya hubungan variabel lain yang tidak diteliti terhadap variabel dependen dalam hal ini adalah espelon $(\varepsilon)$ adapun metode yang digunakan adalah metode analisis regresi linier berganda. Analisis ini untuk melihat arah hubungan dan besar pengaruh hubungan satu sama lain antar variabel. Dalam penelitian adalah bersifat korelatif dan kausalitas yang didahului dengan konversi data yang berskala ordinal menjadi skala interval. Formula analisis linier berganda, sebagai berikut

$$
Y=b_{0}+b_{1} X_{1}+b_{2} X_{2}+b_{3} X_{3}+b_{4} X_{4}+e
$$

Dimana:

$\mathrm{Y} \quad=$ produk rusak

$\mathrm{X} 1=$ biaya pencegahan

$\mathrm{X} 2=$ biaya penilaian

X3 = biaya kegagalan internal

X4 = biaya kegagalan eksternal

$\mathrm{b}_{0} \quad=$ konstanta

$\mathrm{b}_{1}-\mathrm{b}_{4}=$ koefisien regresi yang akan dicari nilainya

$\mathrm{e} \quad=$ standar error

\section{HASIL DAN PEMBAHASAN}

\section{Hasil Analisis Data Statistik}

Setelah dilakukan analisis data statistik dengan menggunakan regresi linier berganda dapat diketahui variable-variabel yang mempunyai hubungan pengaruh baik secara bersama-sama maupun secara terpisah pada variabel independen terhadap variabel dependen. Dari hasil olahan data terhadap 81 orang responden, maka dapat didapatkan persamaan berikut: 


$$
Y=0,443 X_{1}+0,244 X_{2}+0,221 X_{3}+0,313 X_{4}+0,453 e
$$

Hasil persamaan tersebut dapat dijelaskan sebagai berikut :

a. Angka koefisien $\mathrm{X} 1=0,443$ hal ini menandakan bahwa biaya pencegahan (X1) terhadap produk rusak (Y) didapatkan pengaruh yang signifikan dan positif. Besarnya pengaruh biaya pencegahan terhadap produk rusak sebesar $44,3 \%$.

b. Angka koefisien $\mathrm{X} 2=0,244$ hal ini menandakan bahwa biaya penilaian (X2) terhadap produk rusak (Y) didapatkan pengaruh yang signifikan dan positif. Besarnya pengaruh biaya penilaian terhadap produk rusak sebesar $24,4 \%$.

c. Angka koefisien X3 =0,221 hal ini menandakan bahwa biaya kegagalan internal (X3) terhadap produk rusak (Y) didapatkan pengaruh yang signifikan dan positif. Besarnya pengaruh biaya kegagalan internal terhadap produk rusak sebesar $22,1 \%$.

d. Angka koefisien X4 = 0,313 hal ini menandakan bahwa biaya kegagalan eksternal (X4) terhadap produk rusak (Y) didapatkan pengaruh yang positif dan signifikan. Besarnya pengaruh biaya kegagalan eksternal terhadap produk rusak sebesar 31,3\%.

Sedangkan $\varepsilon=0,453$ menunjukan bahwa standar error sebagai variabel-variabel lain yang tidak diteliti dan memiliki pengaruh terhadap produk rusak sebesar 45,3\%. Memahami hasil hitungan analisis regresi linier berganda yang digunakan, dapat diinterpretasikan terhadap nilai $\mathrm{R}$ square (koefisien determinasi) adalah 0,547. Makna dari hasil tersebut adalah $54,7 \%$ biaya kualitas berpengaruh terhadap produk rusak pada PT. Faninda Jaya Meubel Gorontalo, dijelaskan oleh biaya pencegahan, biaya penilaian, biaya kegagalan internal, biaya kegagalan eksternal serta masih ada sekitar 45,3\% di pengaruhi oleh variabel lain.

Sebagai hasil analisis dari variabel independen tersebut diperoleh informasi bahwa yang paling dominan berpengaruh adalah biaya pencegahan (X1) dengan nilai sebesar 0,443 . Biaya pencegahan adalah biaya yang diadakan untuk melakukan pencegahan terhadap rusaknya produk dari sebuah perusahaan. Sehingga semakin di tingkatkan biaya pencegahan maka semakin menurun hasil produksi produk rusak.

Kemudian biaya kegagalan eksternal (X4) sebesar 0,313 yang dominan berpengaruh terhadap produk rusak. Biaya kegagalan eksternal adalah biaya yang diadakan karena adanya produk atau jasa tidak memenuhi syarat yang dipahami terhadap produk yang dikirimkan terhadap para pelanggan. Penyebab terjadinya produk rusak kemungkinan besar terjadi karena kecerobohan pada saat pemindahan barang dari mobil ke dalam ruangan. Perusahaan harus lebih meningkatkan biaya penanganan keluhan selama masa garansi dan diluar masa garansi agar konsumen tidak khawatir atas kerusakan yang diketahui setelah barang dibeli.

Serta biaya penilaian (X2) sebesar 0,244 yang kurang berpengaruh terhadap produk rusak. Biaya penilaian merupakan biaya yang tejadi untuk menentukan apakah produk dan jasa sesuai dengan persyaratan-persyaratan kualitas. Biaya penilaian harus ditingkatkan untuk menghindari terjadinya kesalahan dan kerusakan sepanjang proses.

Dan biaya kegagalan internal (X3) sebesar 0,221. Biaya kegagalan internal yang paling kurang pengaruhnya terhadap produk rusak karena didalam perusahaan sudah ada biaya pencegahan dengan biaya penilaian sehingga produk rusak yang ada di dalam perusahan cenderung lebih sedikit. Biaya kegagalan internal adalah biaya yang diadakan disebabkan ketidakcocokan terhadap syarat yang diketahui pada saat barang atau jasa tersebut dikirimkan kepada pelanggan.

Hasil penelitian diatas dapat diringkas seperti pada tabel dibawah ini : 
Tabel 3. Pengaruh Biaya Kualitas Terhadap Produk Rusak

\begin{tabular}{|l|c|c|c|}
\hline \multicolumn{1}{|c|}{ Keterangan } & $\begin{array}{c}\text { Pengaruh } \\
\text { langsung }\end{array}$ & $\begin{array}{c}\text { Pengaruh tak } \\
\text { langsung }\end{array}$ & Persentase (\%) \\
\hline X1 - Y & 0,443 & - & 44,30 \\
\hline X2 - Y & 0,244 & - & 24,40 \\
\hline X3 - Y & 0,221 & - & 22,10 \\
\hline X4 - Y & 0,313 & 31,30 \\
\hline Pengaruh variabel X1, X2, X3, dan X4 terhadap Y & 54,70 \\
\hline \multicolumn{2}{|l|}{ Pengaruh variabel lain terhadap Y } & 45,30 \\
\hline Total & 100 \\
\hline
\end{tabular}

Sumber : data olahan SPSS 21

\section{Hubungan Korelasi Antar Variabel X \\ Hubungan Korelasi X1}

Berdasarkan hasil olahan data dapat diketahui bahwa hubungan (korelasi) antara biaya pencegahan (X1) terhadap biaya penilaian (X2) sebesar 0,235, dapat dimaknai bahwa kedua variabel tersebut terdapat hubungan korelasi rendah yakni 0,235 atau $23,5 \%$.

Berdasarkan hasil olahan data dapat diketahui bahwa hubungan (korelasi) antara biaya pencegahan (X1) terhadap biaya kegagalan internal (X3) sebesar 0,291, dapat dimaknai bahwa kedua variabel tersebut terdapat hubungan korelasi rendah yakni 0,291 atau $29,1 \%$.

Berdasarkan hasil olahan data dapat diketahui bahwa hubungan (korelasi) antara biaya pencegahan (X1) terhadap biaya kegagalan eksternal (X4) sebesar 0,084, dapat dimaknai bahwa kedua variabel tersebut terdapat hubungan korelasi sangat rendah yakni 0,084 atau $8,4 \%$.

\section{Hubungan Korelasi X2}

Berdasarkan hasil olahan data dapat diketahui bahwa hubungan (korelasi) antara biaya penilaian (X2) terhadap biaya pencegahan (X1) sebesar 0,235 , dapat dimaknai bahwa kedua variabel tersebut terdapat hubungan korelasi rendah yakni 0,235 atau $23,5 \%$.

Berdasarkan hasil olahan data dapat diketahui bahwa hubungan (korelasi) antara biaya penilaian (X2) terhadap biaya kegagalan internal (X3) sebesar 0,020, dapat dimaknai bahwa kedua variabel tersebut terdapat hubungan korelasi sangat rendah yakni $-0,020$ atau $2,0 \%$.

Berdasarkan hasil olahan data dapat diketahui bahwa hubungan (korelasi) antara biaya penilaian (X2) terhadap biaya kegagalan eksternal (X4) sebesar 0,049, dapat dimaknai bahwa kedua variabel tersebut terdapat hubungan korelasi sangat rendah yakni 0,049 atau $4,9 \%$.

\section{Hubungan Korelasi X3}

Berdasarkan hasil olahan data dapat diketahui bahwa hubungan (korelasi) antara biaya kegagalan internal (X3) terhadap biaya pencegahan (X1) sebesar 0,291, dapat dimaknai bahwa kedua variabel tersebut terdapat hubungan korelasi rendah yakni 0,291 atau $29,1 \%$. 
Berdasarkan hasil olahan data dapat diketahui bahwa hubungan (korelasi) antara biaya kegagalan internal (X3) terhadap biaya penilaian (X2) sebesar 0,020 dapat dimaknai bahwa kedua variabel tersebut terdapat hubungan korelasi sangat rendah yakni 0,020 atau $2,0 \%$.

Berdasarkan hasil olahan data dapat diketahui bahwa hubungan (korelasi) antara biaya kegagalan internal (X3) terhadap biaya kegagalan eksternal (X4) sebesar 0, dapat dimaknai bahwa kedua variabel tersebut terdapat hubungan korelasi sangat rendah yakni 0,059 atau $5,9 \%$.

\section{Hubungan korelasi X4}

Berdasarkan hasil olahan data dapat diketahui bahwa hubungan (korelasi) antara biaya kegagalan eksternal (X4) terhadap biaya pencegahan (X1) sebesar 0,084, dapat dimaknai bahwa kedua variabel tersebut terdapat hubungan korelasi sangat rendah yakni 0,084 atau $8,4 \%$.

Berdasarkan hasil olahan data dapat diketahui bahwa hubungan (korelasi) antara biaya kegagalan eksternal (X4) terhadap biaya penilaian (X2) sebesar 0,049, dapat dimaknai bahwa kedua variabel tersebut terdapat hubungan korelasi sangat rendah yakni 0,049 atau $4,9 \%$.

Berdasarkan hasil olahan data dapat diketahui bahwa hubungan (korelasi) antara biaya kegagalan eksternal (X4) terhadap biaya kegagalan internal (X3) sebesar 0,059, dapat dimaknai bahwa kedua variable tersebut terdapat hubungan korelasi sangat rendah yakni 0,059 atau 5,9\%.

\section{PEMBAHASAN HASIL PENELITIAN}

Biaya kualitas yang terdiri dari biaya pencegahan, biaya penilaian, biaya kegagalan internal dan biaya kegagalan eksternal secara simultan berpengaruh positif terhadap produk rusak

Biaya kualitas yang terdisi dari biaya pencegahan, biaya penilaian, biaya kegagalan internal dan biaya kegagalan eksternal secara simultan mempunyai korelasi positif terhadap produk rusak yaitu 0,547 atau $54,7 \%$. Ini ditunjukan terhadap biaya kualitas yang terdiri dari biaya pencegahan, biaya penilaian, biaya kegagalan internal dan biaya kegagalan eksternal secara bersama-sama mempunyai pengaruh positif terhadap produk rusak. Dengan demikian, jika biaya kualitas yang terdiri dari biaya pencegahan dan biaya penilaian secara sama-sama ditingkatkan maka akan menurunkan produk rusak sebesar $54,7 \%$ dan sisianya $45,3 \%$ merupakan variabel luar yang ikut mempengaruhi produk rusak yaitu pengalaman tenaga kerja dan listrik. Karna jika hasil produksi yang dikerjakan oleh seseorang yang sudah berpengalaman maka kerusakan yang dihasilkan kemungkinan kecil, begitupun sebaliknya. Untuk listrik juga dapat mempengaruhi hasil produksi, jika saat proses produksi terjadi pemadaman listrik maka akan mempengaruhi kualitas produk yang dihasilkan. Biaya kualitas akan dilakukan oleh perusahaan dalam mengatasi munculnya kualitas produk yang turun. Dengan dilakukannya biaya kualitas dalam rangka meningkatkan kualitas produk, demi menghasilkan produk dapat terjaga agar dapat terterima pasar secara umum

Dalam penelitian ini sejalan terhadap apa yang dikatakan oleh fandi dan Anastasia dimana, biaya kualitas adalah biaya yang timbul diakibatkan dari kualitas yang rendah. Jadi, biaya kualitas adalah biaya yang mempunyai hubungan dengan penciptaan, pengidentifikasian, upaya mengatasi kerusakan. Hasil penelitian dilakukan Endah Lestari 
(2014) didapatkan bahwa biaya kualitas selalu meningkat tiap tahun, namun biaya-biaya yang timbul itu bisa ditekan seiring perkembangan untuk melakukan perbaikan terhadap produk. untuk meningkatkan daya jual perusahaan dapat dipengaruhi oleh biaya kualitas meskipun selebihnya faktor lain yang mempengaruhinya. Secara bersama-sama biaya kualitas yang meliputi biaya pencegahan, biaya penilaian, biaya kegagalan internal, dan biaya kegagalan eksternal memiliki korelasi terhadap penjualan pada PT. Mitra Sejati Mulia Industri selama tahun 2009-2012.

\section{Biaya pencegahan secara parsial berpengaruh positif dan signifikan terhadap produk rusak}

Berdasarkan hasil analisis data menunjukan bahwa biaya kualitas yang terdiri dari biaya pencegahan secara terpisah berpengaruh positif dan signifikan terhadap produk rusak sebesar 0,443 (44,3\%). Hasil ini menunjukan bahwa terdapat pengaruh positif terhadap produk rusak, memiliki makna bahwa biaya pencegahan ditambah, akan dikuti dengan penurunan produk rusak sebesar 44,3\%. Besar pengaruh variabel tersebut terungkap berdasarkan hasil sebaran kuisioner ke sejumlah responden karyawan PT. Faninda Jaya Meubel yang berada di Kab. Gorontalo.

Dengan hasil analisis data ini menunjukan bahwa biaya pencegahan sangat memberi kontribusi pengaruh terhadap produk rusak. Hal ini juga didasarkan pada tanggapan responden, dimana hasil pengukuran menunjukan bahwa produk rusak yang berada di PT. Faninda Jaya Meubel memiliki respon yang rendah terhadap biaya pencegahan, akan tetapi meskipun tanggapan responden rendah terhadap biaya kualitas, responden tetap memandang segala bentuk biaya pencegahan dapat menurunkan hasil produksi produk rusak.

Penyebab biaya pencegahan merupakan biaya yang dikurangi atau menghilangkan masalah-masalah dan menjadi biaya satu-satunya biaya menambah diantara biaya kualitas lain. Biaya pencegahan yang terdiri dari biaya perencanaan dan pemeriksaan produk, biaya pemeliharaan mesin, dan biaya tenaga kerja. Penelitian ini sejalan dengan teori yang diungkapkan oleh Hansen dan Mowen, yang mengungkapkan biaya pencegahan ditingkatkan dapat menurunkan produk rusak.

\section{Biaya penilaian secara parsial berpengaruh positif dan signifikan terhadap produk rusak}

Berdasarkan hasil analisis data menunjukan bahwa biaya kualitas yang terdiri dari biaya penilaian secara parsial berpengaruh positif dan signifikan terhadap produk rusak sebesar 0,244 (24,4\%). Hasil ini menunjukan bahwa terdapat pengaruh positif terhadap produk rusak, artinya bahwa jika biaya penilaian ditingkatkan, maka akan dikuti dengan penurunan produk rusak sebesar $24,4 \%$.

Besar pengaruh variabel tersebut terungkap berdasarkan hasil sebaran kuisioner ke sejumlah responden karyawan PT. Faninda Jaya Meubel yang berada di Kabupaten Gorontalo. Dapat diketahui bahwa perusahaan telah melakukan pembiayaan untuk mengangkat nilai kualitas produknya. Salah satu biaya yang dikeluarkan adalah biaya kualitas untuk menurunkan produk rusak. Berdasarkan hasil penelitian yang dilakukan, PT. Faninda Jaya Meubel mengeluarkan biaya kualitas untuk meningkatkan kualitas produk. dengan adanya biaya tersebut sedapat mungkin dapat mengatasi kerusakan dari sebuah produk yang dihasilkan. 
Berdasarkan hasil penelitian ini dapat dijelaskan bahwa biaya penilaian mempunyai hubungan terhadap produk rusak. Biaya penilaian tersebut menjadi aktivitas yang dapat mendeteksi produk yang tidak sesuai dengan syarat-syarat kualitas.

Biaya penilaian pada PT. Faninda Jaya Meubel terdiri dari pemeriksaan pengujian bahan baku yang dibeli, pemeriksaan pengujian produk, pemeriksaan kualitas produk dan evaluasi persedian. Biaya pencegahan akan menghilangkan masalah kualitas dan menjadikan biaya satu-satunya yang memiliki nilai tambah terhadap biaya kualitas dan biaya penilaian merupakan kegiatan yang dapat menemukan produk yang rusak sebelum di kirim ke pelanggan. Hasil dari penelitian ini sejalan dengan yang diungkapkan oleh Hansen dan Mowen, yang menjelaskan bahwa biaya penilaian meningkat dapat menurunkan produk rusak.

Penelitian yang dilakukan oleh Arie Eviansyah (2013) jika biaya penilaian ditingkatkan maka jumlah produk rusak akan mengalami penurunan yang kemudian akan menurunkan biaya kegagalan internal. Sejalan dengan penelitian yang dilakukan oleh peneliti.

\section{Biaya kegagalan internal secara parsial berpengaruh positif dan signifikan terhadap produk rusak}

Temuan penelitian mengatakan bahwa terdapat pengaruh positif dan signifikan variabel biaya kegagalan internal (X3) terhadap produk rusak (Y) 22,1\%. Hasil ini menunjukan bahwa terdapat pengaruh positif dan signifikan terhadap produk rusak, artinya bahwa jika biaya kegagalan internal dikeluarkan berarti terdapat produk rusak. Karena pada dasarnya biaya kegagalan dikeluarkan setelah produk itu jadi dan untuk memperbaharui produk yang rusak. Untuk mencegah biaya kegagalan internal perusahaan PT. Faninda Jaya Meubel lebih meningkat biaya pencegahan dan biaya penilaian. Karena biaya pencegahan dan biaya penilaian berpengaruh terhadap hasil produksi produk rusak.

Pengukuran biaya kegagalan internal dilakukan dengan menghitung kerusakan produk sebelum meninggalkan pabrik. Biaya kegagalan internal terdiri dari sisa bahan, pengerjaan ulang, biaya untuk memperoleh material dan factory contact engineering.

Pada dasarnya bahwa biaya kualitas yang muncul oleh perusahaan dengan tujuan untuk menekan adanya produk dengan kualitas menurun. Pengeluaran biaya kualitas dilakukan untuk meningkatkan kualitas produk agar dapat dihasilkan produk yang selalu terjaga dan dapat dihasilkan produk yang dapat diterima oleh pasar. Biaya kegagalan internal dapat dipergunakan untuk menghasilkan produk yang yang sesuai kriteria yang diinginkan oleh pelanggan, meskipun proruk tersebut belum tersampaikan ke pelanggan.

Dalam penelitian ini dijelaskan bahwa biaya kegagalan internal dipengaruhi oleh produk rusak. Biaya kegagalan internal menjadi bagian dari kegiatan yang dapat menemukan produk yang rusak sebelum produk tersebut dikirim kepada pelanggan.

\section{Biaya kegagalan eksternal secara parsial berpengaruh positif dan signifikan terhadap produk rusak}

Temuan penelitian mengatakan bahwa secara parsial terdapat pengaruh positif variabel biaya kegagalan eksternal (X4) terhadap produk rusak (Y) 31,3\%. Jenis biaya ini adalah menjadi biaya yang paling menyeramkan, karena dapat menimbulkan track record yang buruk, dapat menyebabkan kehilangan pelanggan, dan penurunan pangsa pasar. 
Biaya kegagalan eksternal seharusnya tidak perlu ada jika tidak terjadi kerusakan. Hal ini menunjukan bahwa dengan semakin meningkatnya biaya kegagalan eksternal berarti tingkat produk rusak yang terdapat dikalangan konsumen juga meningkat seperti adanya pengembalian produk akan mempengaruhi tingkat pertimbangan konsumen dalam memutuskan pembelian produk kembali. Dengan adanya hal tersebut maka akan berdampak pada pendapatan perusahaan.

PT. Faninda jaya menyediakan garansi terhadap pembelian produk jenis apapun. Untuk garansi perusahaan tidak menentukan seberapa lama waktu yang diberikan sehingga membuat konsumen tidak khawatir jika terjadi kerusakan. Dimana jika kerusakan produk karena bahan kayu yang sudah lapuk maka akan di tanggung setengah oleh perusahaan. Dan jika kerusakan di karenakan kelalaian konsumen, semua biaya ditangguhkan kepada konsumen itu sendiri.

Biaya kegagalan eksternal merupakan yang dikeluarkan akibat adanya produk atau jasa yang tidak memenuhi standar pada saat informasi terkait produk tersebut yang dikirim kepada konsumen atau pelanggan. Yang termasuk dalam biaya kegagalan eksternal yaitu biaya yang dikeluarkan dalam rangka pemenuhan atas keluhan selama masa jaminan perusahaan atau garansi, biaya pemenuhan atas keluhan diluar masa jaminan atau garansi, pelayanan terhadap produk, kewajiban produk, dan biaya yang dikeluarkan apabila produk tersebut dilakukan penarikan.

Berdasarkan penelitian yang telah di lakukan oleh Rahmi M (2015) dalam penelitian tersebut mendapatkan bagian besar biaya ke gagalan eskternal yang dikeluarkan oleh perusahaan yaitu dari biaya pengggantian terhadap produk yang menjadi keluhan pelanggan terhadap produk yang dihasilkan perusahaan. Keluhan tersebut sering muncul atas makanan yang tidak bisa di makan dalam hal ini basi, dalam rangka mengurangi hal tersebut perusahaan wajib mengeluarkan beberapa biaya sebagai pencegahan, dengan melakukan coaching dan pelatihan terhadap karyawan produksi dalam rangka mempelajari hal-hal yang berkaitan dengan bagaimana bisa terhindar dari persoalan yang ditimbulkan akibat dari kerusakan hasil olahan makanan tersebut.

Hikmah dibalik dari adanya biaya kegagalan akan berkaitan dengan gambaran terhadap produk/merk, dengan melakukan kembali penarikan produk-produk yang telah dihasilkan namun rusak tetapi sudah beredar, maka gambaran terhadap kualitas dari produk itu diupayakan untuk selalu terjaga dengan baik, yang memungkinkan untuk membuat pelanggan loyal terhadap produk yang dihasilkan oleh perusahaan.

Taguchi mendefenisikan biaya kualitas dalam penelitian (Monika. 1999), adalah sejumlah kerugian yang muncul dan harus dipikul oleh perusahaan apabila produk yang dihasilkan menyimpang dari nilai target, walaupun produk tersebut masih berada dalam batas spesifikasi produk yang dihasilkan. Akibat dari adanya produk yang tidak sesuai dengan target, maka memang seharusnya perusahaan mengeluarkan biaya untuk memperbaiki kualitas.

\section{KESIMPULAN}

Sesuai hasil penelitian ini, maka penulis menarik sebuah kesimpulan bahwa : biaya yang dikeluarkan perusahaan dalam rangka mengatasi persoalan terkait dengan produk rusak menjadi sebuah ukuran standar dalam rangka menghadirkan produk yang punya kualitas baik dan dapat terterima oleh konsumen atau pelanggan. Beberapa biaya tersebut seharusnya tidak terjadi namun oleh perusahaan harus dikeluarkan karena berkaitan dengan keinginan perusahaan untuk menghadirkan produk dengan kualitas yang lebih 
baik. Dengan adanya produk rusak yang ditemukan maka dapat membenankan kepada perusahaan dengan kondisi keuangan perusahaan untuk dikeluarkan dalam rangka perbaikan produk yang rusak.

\section{DAFTAR PUSTAKA}

Arie Erviansyah. 2013. Analisis Pengaruh Biaya Kualitas Terhadap Produk Rusak Pada PT. Nusa Toyotetsu Corporation. Management Analysis Journal. 2013;2(2):1-7. doi: http://journal.unnes.ac.id/sju/index.php/maj

Endah Lestari RM, Hakim MM. 2014. Pengaruh Biaya Kualitas Terhadap Tingkat Penjualan Pada Pt Mitra Sejati Mulia Industri. JIAFE (Jurnal Ilm Akunt Fak Ekon. 2014;6(2):34-41. DOI: http://10.34204/jiafe.v6i2.530

Hansen Dan Mowen, 2009, Akuntansi Manajerial, Edisi 8, Buku 2,penerbit PT. Salemba Empat jakarta.

Krismiaji Dan Y. Anni Aryani , 2011, Akuntansi Manajemen, Edisi 2.penerbit YKPN Yogyakarta .

M N, Munawarah. 2018. Pengaruh Biaya Kualitas Terhadap Produk Rusak (Studi Kasus Pada Koran Radar Sulbar) Kabupaten Polewali Mandar. J JITU. 2018;8(1):87-98.

Monika Kussetya Ciptani. 1999. Pengukuran Biaya Kualtas : Suatu Paradigma Alternatif. Jurnal Akuntansi dan Keuangan, 1999;1(1): 68-83. DOI : https://doi.org/10.9744/jak.1.1.pp.\%2068-83

Mulyadi. 2012. Akuntansi Biaya, Unit Penerbit dan Percetakan Sekolah Tinggi Ilmu Manajemen YKPN, Yogyakarta. , 2015, Akuntansi Biaya, Edisi 5, penerbit YKPN Yogyakarta.

Rahmi M, Rosalina E, Rosita I. 2015. Penerapan Biaya Kualitas Dalam Meningkatkan Efisiensi Biaya Produksi Pada Catering ABC. Akuntansi dan Manajemen. 2015;10 (1) : 25-35. DOI: http://10.30630/jam.v10i1.109

Sugiyono, 2012, Metode Penelitian Kuantitatif, Kualitatif Dan R\&D, Cetakan Ke 17, Penerbit CV. Alfabeta, Bandung. 2010, Metode Penelitian Bisnis, Cetakan Ke 15, Penerbit CV. Alfabeta, Bandung.

Tjiptono, Fandi, Diana Anastasia. 2003. Total Quality Management. Yogyakarta : Penerbit Andi. 